Article

\title{
The association of parental interest in entrepreneurship to the entrepreneurial interest of Spanish youth
}

\author{
María-Isabel Luis-Rico ${ }^{1 *}$, María-Camino Escolar-Llamazares ${ }^{2 *}$, Tamara de la Torre-Cruz ${ }^{1}$, \\ Álvaro Herrero ${ }^{3}$, Carmen Palmero-Cámara ${ }^{1}$, Alfredo Jiménez-Eguizábal 1 ${ }^{1}$, and Alfredo Jiménez 4 \\ 1 Departamento de Ciencias de la Educación; Universidad de Burgos; Avda. Villadiego, nº1. 09001. Spain; \\ miluis@ubu.es (M.I.L.R.); tdtorre@ubu.es (T.D.L.T.C.); cpalmero@ubu.es (CPC); ajea@ubu.es (AJE). \\ 2 Departamento de Ciencias de la Salud; Universidad de Burgos; Paseo Comendadores s/n. 09001. Spain; \\ cescolar@ubu.es \\ 3 Grupo de Inteligencia Computacional Aplicada (GICAP); Departamento de Ingeniería Civil, Escuela \\ Politécnica Superior; Universidad de Burgos; Avda. Cantabria, s/n. 09006. Spain; ahcosio@ubu.es \\ 4 Department of Management; KEDGE Business; 680 Cours Libération. 33405. Talence. France; \\ alfredo.jimenez@kedgebs.com \\ * Correspondence: miluis@ubu.es (M.I.L.R.); cescolar@ubu.es (M.C.E.LL.)
}

\begin{abstract}
As entrepreneurial interest is believed to represent a causal factor increasing entrepreneurship, research has begun to explore how family systems affect youth entrepreneurial interests. In the present study, we attempt to identify different types of family influence on the entrepreneurial interests of young people. A questionnaire was used to obtain data from 1,633 Spanish youths, who were 15 to 18 years old, and another questionnaire was used to obtain data from 839 parents. Principal Component Analysis identified unique family types and revealed that they have differential associations to entrepreneurial interest among youths. These findings reaffirm the influence of family on the entrepreneurial ecosystem and the promotion of an entrepreneurial family cuture. This study further suggests that early attention should focus on the detection of entrepreneurial interest among youths so that actions can be implemented in the families of lowinterest youths to incentivize an entrepreneurial family culture.
\end{abstract}

Keywords: entrepreneurship; entrepreneurial interest; youth, family; entrepreneurial eco-system; principal component analysis

\section{Introduction}

The past few years have seen increasing attention given to promoting entrepreneurship evident in interdisciplinary programs [1,2] and increasing social scientific research [3-5]. Although entrepreneurship cannot be thought to be the only solution for current social and economies woes, it is a relevant topic that affects almost 500 million people every year and is related to the creation of new enterprises [6], which has been identified as one of the key components for growth and social and economic development [7-10].

Considering these trends, it is hardly surprising that entrepreneurship as a multi-dimensional dynamic has awakened unprecedented interest in the field of economics. Various economic variables have been employed to study the impact of entrepreneurship on the growth of productivity, competitiveness, economic growth, job creation, and even self-fulfillment [11]. However, despite scientific progress, we continue to be partially unaware of the behavior and efficacy of the relationship between entrepreneurial initiatives and behaviors and continue to have difficulty explaining a large part of the variation of this activity [12-16]. In addition, policies of international scope that have centred on measures to stimulate entrepreneurial activity, the removal of barriers through grants, and the simplification of administrative procedures are yet to achieve the expected results [17-19]. The deterministic conception of international policies lacks the pluralist and 
interdisciplinary views required to foster entrepreneurial interest, intention and decision-making, to move forward with the task of business creation and to understand the conditions affecting the situation and the timeframe $[17,20,21]$.

For this reason, scholars have also pointed out that, in addition to the economic effects of entrepreneurship, it is also critical to analyze its implicit risks [22], as well as the socio-educational aspects that are often determining factors of entrepreneurship $[23,24]$. In this context, entrepreneurial orientation and skills are emerging as a supra-national educational trend in the European Union as in other geo-cultural areas $[25,26]$ together with the implementation of different strategies and training plans at a practical level, which are aimed at increasing the numbers of firms and the employability of the population [27-30]. To achieve this goal, this paper aims to explore the relationship between family interest and support and the entrepreneurial interest of young people

\subsection{Review of the scientific literature}

Entrepreneurship may be considered the creation of ideas, businesses, and patents, as well as their incubation processes, even in cases where these ideas are not put into practice [7-9]. It is precisely the process that precedes the action where entrepreneurial intention and its influential variables assume relevance to explain the two interrelated processes that constitute entrepreneurship, namely the discovery of opportunities and their exploitation [13,14,31].

In this regard, research has considered entrepreneurial intention as a multidimensional construct that is determined by a varied set of aspects [32]. For example, Fayolle and Gailly [33] pointed out how different investigations have shown the importance of social status, cultural norms, and the model of parents and close relatives. The investigation into entrepreneurial intention among students is still at an exploratory stage that is undergoing theoretical and conceptual development [34,35]. In this sense, Fayolle and Liñan [35] considered that a greater understanding of entrepreneurial intention can contribute to a better entrepreneurial decision-making process at the personal level which, in turn, allows the design of more effective education initiatives.

This trend has generated different lines of investigation in the study of the factors relating to entrepreneurial intention among students. Previous scientific literature has manily focused on two of the most relevant areas: one is focused on the study of entrepreneurial interest as a previous stage of entrepreneurial intention; and the other one on the variables that influence entrepreneurial intention and particularly on the variables of a relational or family nature, as well as educational, and psychological variables [36].

The first of the research lines analyzed some aspects of the antecedents to entrepreneurial intention by centering on entrepreneurial interest, building on the Social Cognitive Career Theory (SCCT) of Lent et al. [37,38]. SCCT explains the mechanisms through which individuals exercise control over the behaviors involved in the development of their careers. This is especially useful in explaining the initial phases of career decisions and the vocational behavior of adolescents and young adults immersed in their preparations for access to the world of work [39].

According to SCCT, the development of career goals (career choice process) is conceived as a sequence of interests, intentions, and behaviors that are presented as occupational choices where career intentions arise from the previous training of vocational interests [37]. The interests stimulate the career intentions or choice of goals (the plans of dedicating oneself to a certain activity and to achieve a certain result in the future), which increase the probability of making a career choice behavior (specific actions that mark the entry of the individual into an academic or professional line of work) $[36,37,40]$.

The construct of entrepreneurial interest and its consequent impact on the construction of employment projection has typically been studied in adolescence [41,42], a time when the consolidation of professional interests is considered to start [36].

The second research lines centered on the variables that influenced entrepreneurial intention, in particular relational, socio-educational, and psychological factors (see Figure 1). The insufficient predictive power of each one may be highlighted as well as the need to identify the psychosocial and educational profiles of future entrepreneurs to establish training [10,29,43-46]. 


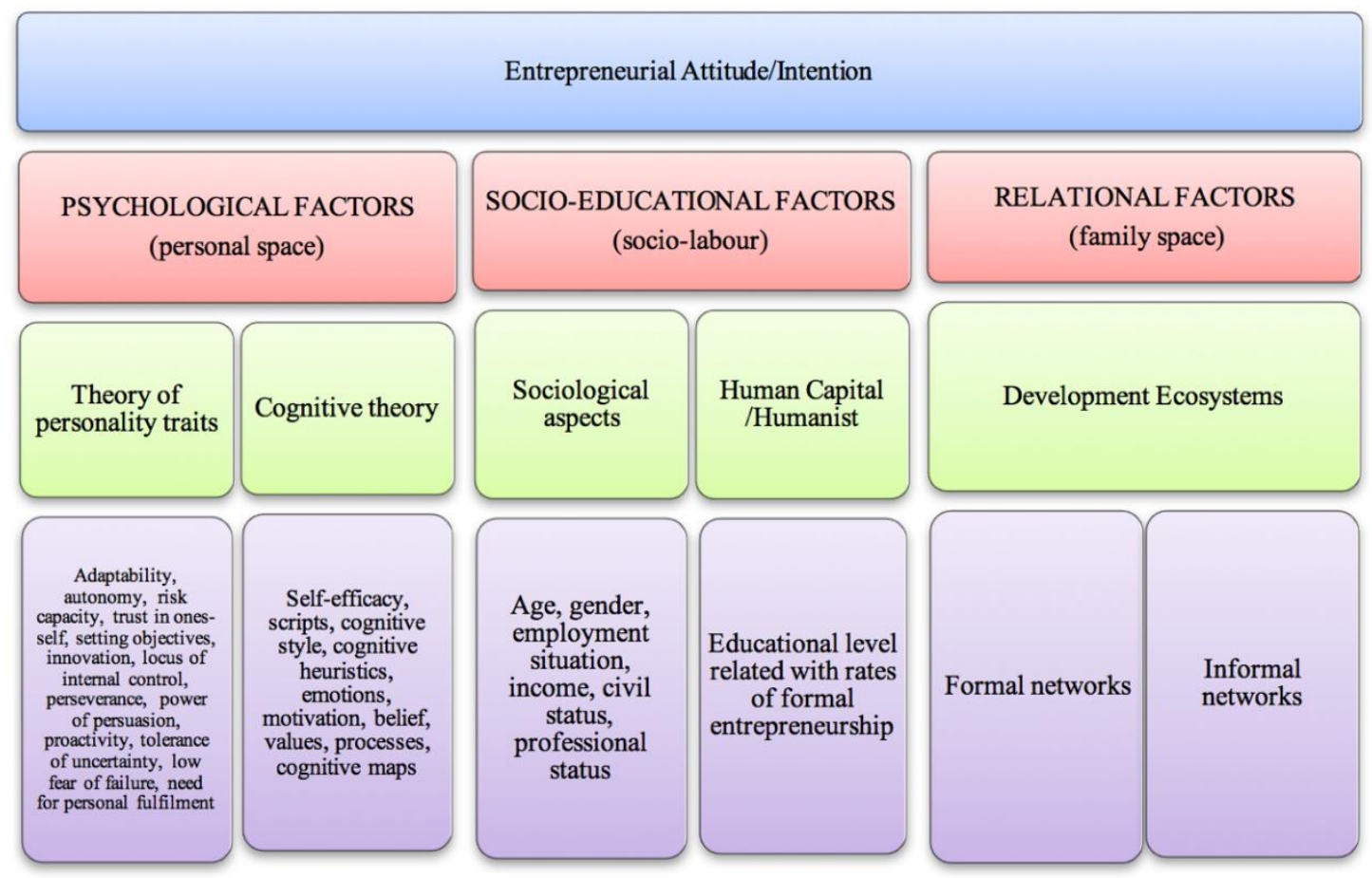

Figure 1. Factors influencing entrepreneurial intention, grouped according to the model of Sonnenfelt et al. [47].

Research on the psychological factors (personal space) related to entrepreneurial interest and its implementation has focused on the characteristics, attributes and features of people who decide to start and entrepreneurial venture. Two main theoretical perspectives have arisen, one based on the personality trait approach and the other ones on the cognitive approach [39,43,48-51].

Studies focused on the socio-educational factors (socio-labour) have traditionally focused on variables related to age, gender, work situation, income, and status, among others, as the determining factors of entrepreneurial interest [52,53]. However, arguably the factor that has received the most attention has been the decisive influence of education in the empowerment of people and the increase of entrepreneurial rates [54-56].

Finally, regarding relational factors (family space), previous research has shown that the social models provided by the family setting positively influence the development of a professional career through self-employment [57,58], i.e., coming from a nuclear family with a business link means that the person is introduced little by little into the world of entrepreneurship [44,59-63].

The scientific literature points to the family as being one of the main relational factors capable of influencing the young individual for the creation of a business or work on your own [64]. Similarly, the family is presented as a factor capable of predicting the intention of creating a company [64-66]. Authors such as Heck and Rogoff [67] pointed out that one of the fundamental pillars of entrepreneurship is the family, together with financial resources, human resources, educational, and economic conditions. These authors considered that at every stage of a venture, the family connection is fundamental. The sharing of resources, including social networks, between the family and business is a major influence on the ability of each to thrive a venture's ability Similarly, Heck and Rogoff [67] considered that entrepreneurship cannot be started or grow without the mobilization of the family.

Aldrich and Cliff [16] established that people are not atomized decision-makers, but rather, are implicated in networks of social relations. In this sense, some authors have highlighted the effect that the perceived entrepreneurial environment has on the students'entrepreneurial intention $[68,69]$. Thus, individuals do not decide to start a business in a vacuum; instead, they consult and are subtly influenced by other significant people in their environment, such as their family. Several studies have indicated that, during the start-up process, family plays an important role in the mobilization of 
financial resources, the provision of human resources and physical resources in the form of space in the family household [16]. In the same vein, Bolaños [60] highlighted how many entrepreneurs decide to start a business simply by seeing a family member who is successful in their business. Similarly, students who belong to families with a family business perceive a more positive social pressure, both from their immediate environment and from society, with respect to entrepreneurship [70]. Gibb Dyer [15] pointed out the positive impact of the "family effect" on firm performance, in aspects such as firm governance, its basic characteristics, the quality of its management, and possibly even industry.

All this evidence has made authors like Heckf and Rogoff [67] wonder how the role of the family has been largely overlooked as a key factor of entrepreneurship, despite permeating most business ventures, surrounding virtually every entrepreneur, and providing a greater source and origin of education and values that are critical to entrepreneurs. Gibb Dyer [15] clearly pointed out how most studies ignore the impact of factors such as the family on the performance of a company and in fostering of entrepreneurial interest. Similarly, Aldrich and Cliff [16] questioned how, despite increased research on the crucial aspect of entrepreneurship, very little attention has been paid to how family dynamics affect fundamental entrepreneurial processes. Further studies are needed on how family systems affect opportunity emergence and recognition, the new venture creation decision, and the resource mobilization process. Similarly, more research is needed on the role that family characteristics and dynamics play in who, when, and how some people, but not others, identify entrepreneurial opportunities and decide to start business enterprises [16].

In sum, mounting empirical evidence has suggested that families play an important role in the venture creation process and thus deserve greater consideration in entrepreneurship and therefore in the entrepreneurial interest of young people.

Accordingly, and responding to the gaps mentioned above in theoretical investigation, the objectives of this study are:

Objective 1. To describe the association between interest in entrepreneurship among Spanish youths and the family's interest in their child becoming entrepreneurial

Objective 2. To examine the association between interest in entrepreneurship among Spanish youths and the family support that the young person would receive if he decided to become an entrepreneur

Objective 3. To analyze what kind of family support is more prevalent among Spanish youths with high entrepreneurial interest and with families with a high interest in their children being entrepreneurs.

\section{Materials and Methods}

We conducted a questionnaire-based transversal descriptive study of a population with a probabilistic sample as part of a project coordinated at the national level and developed by the universities of Barcelona, Burgos, Deusto, La Rioja, and Santiago de Compostela and the UNED. The questionnaire had two parts, one to be filled in by the students (Student Questionnaire) and another to be filled in by the families of the students (Family Questionnaire). In addition, the University Pablo de Olavide de Seville and the University of Valencia assisted with the data collection activities

\subsection{Sample and procedure}

The student population under study comprised students 15-18 years old from non-compulsory secondary education who were enrolled at teaching centres in Spain. The questionnaire for students was carried out through a stratified sampling by autonomous communities and educational centers. Based on data from the Ministry of Education, Culture and Sport, we targeted 1,764 students to achieve a confidence level of $95 \%$ with an error margin of $2.3 \%$. However, 131 questionnaires were considered null due to missing responses and therefore removed from the final sample. Consequently, the final 
sample of students was 1633 (92.57\% response rate). Regarding parents, 1764 questionnaires were sent to the parents of the students, and we received 839 valid responses ( $47.56 \%$ response rate).

Simple random sampling was used, maintaining the proportionality for each of the autonomous regions and for each educational level (67\% high school students, $32.7 \%$ students of medium-grade vocational training and $10.3 \%$ students of basic vocational training). The sampling units were selected from sectors during the 2013/14 academic year by selecting educational centres from each autonomous region at random, considering two criteria: one rural centre in each autonomous region and a proportion of one private-state-assisted centre for every three-public educational centres. The questionnaire was administered at each of the selected centres to the number of students needed to cover the sampling quota. This field work occurred during the months of March and June 2014. Permission was sought from both the General Director of Education in each autonomous region and the directors of the educational centres prior to the administration of the questionnaire, and the directors were informed of the rationale behind the research. Two duly trained researchers personally attended the administration of the questionnaire at each centre with a view to following a properly standardized protocol of action. The sample of students comprised $50.1 \%$ women $(n=885)$ and $49.9 \%$ men $(n=879)$. The average age of the participants was 17.6 years old $(S D=1.60)$, and $89.6 \%$ of the participants were of Spanish nationality $(\mathrm{n}=1.581)$.

The present study was funded by the Ministry of Economy, Industry and Competitiveness and the European Regional Development Fund (Spain), which requires no ethics committee approvals for studies in the field of social and legal sciences.

\subsection{Variables and instruments}

Due to the different interests of each of the universities collaborating in the study, the questionnaire was divided into the following thematic sections: students, life at the educational centre, free time, family life, health and quality of life, studies and the labor market in the future, and entrepreneurship.

A pilot test in eight Autonomous Regions was completed to validate the questionnaire, establishing the stratification of the final sample and its proportionality as criteria. The number of questionnaires amounted to $10 \%$ of the subsequent sample. The pilot survey and results were then evaluated by fourteen experts from seven Spanish universities, who approved the definitive version and rated it as highly reliable. Likewise, the reliability of this questionnaire was contrasted with previous studies published by other authors [36,71,72].

So as to meet the proposed objective, the student and family questionnaires were constructed of sections relating to the social, educational, occupational and entrepreneurial variables (see Table 1).

Table 1. Selection of questions/variables from the Student Questionnaire and the Family Questionnaire.

\begin{tabular}{ccccc}
\hline Respondents & $\begin{array}{c}\text { Question } \\
\text { number and } \\
\text { type of } \\
\text { Questionnair } \\
\text { e }\end{array}$ & $\begin{array}{c}\text { Section of } \\
\text { Questionna } \\
\text { ire }\end{array}$ & Data & Measures \\
\hline Student & $\begin{array}{c}\text { Q.1 } \\
\text { Student } \\
\text { questionnaire }\end{array}$ & Students & Sex & Woman/man \\
\hline Student & $\begin{array}{c}\text { Q.10 } \\
\text { Student } \\
\text { questionnaire }\end{array}$ & Q.10.1 & $\begin{array}{c}\text { Parental } \\
\text { education }\end{array}$ & $\begin{array}{c}\text { Only the father with higher } \\
\text { education / Both with higher } \\
\text { education / Only the mother } \\
\text { with higher education / None } \\
\text { with higher education }\end{array}$ \\
\cline { 2 - 5 } Student & Q.10.2 & $\begin{array}{c}\text { Entrepreneur } \\
\text { families }\end{array}$ & Only the entrepreneur father \\
\hline
\end{tabular}




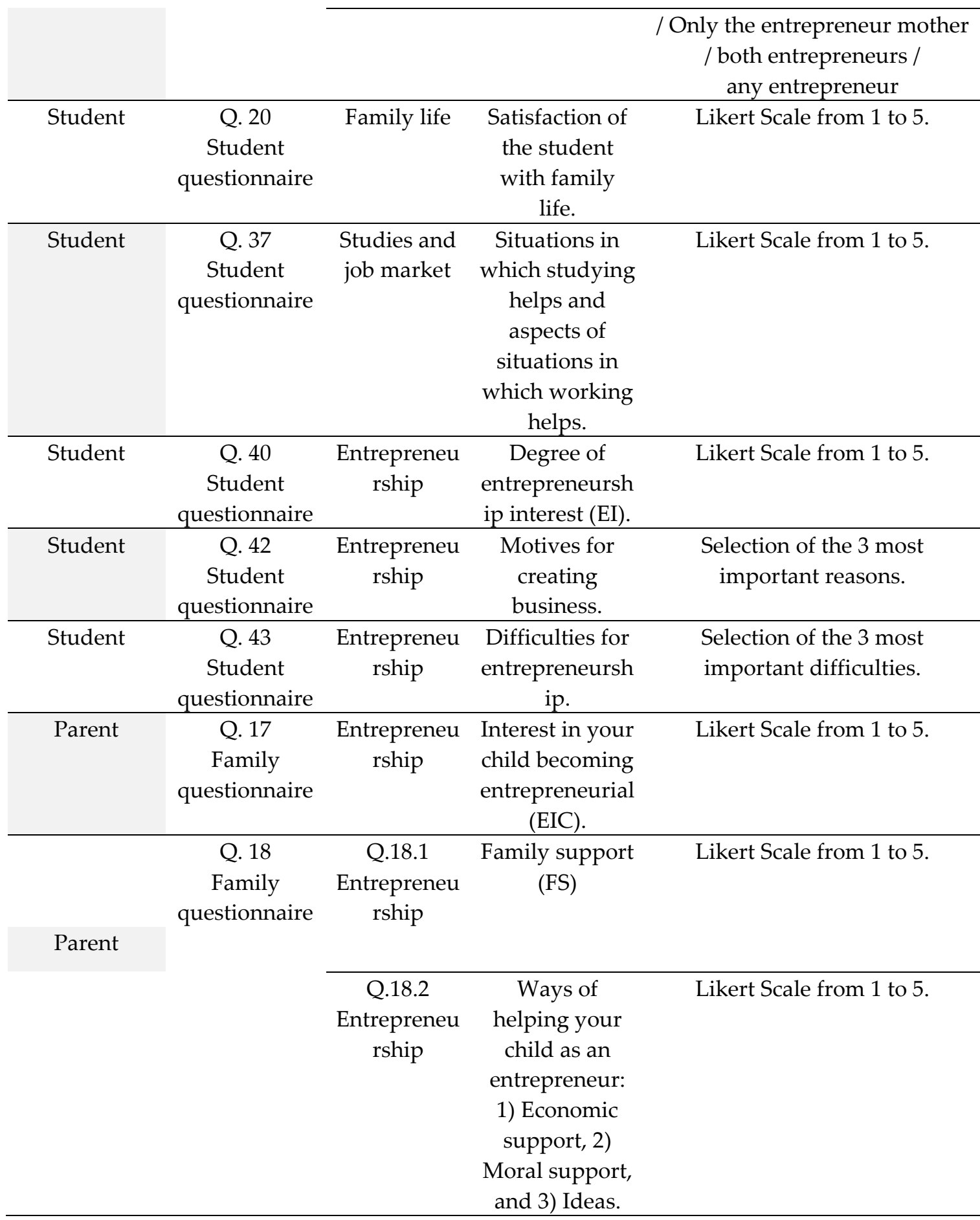

\subsection{Data analysis}

Having selected the questions/variables included in the study, a code was used as an identifier of each datum, thereby yielding a data set with 1,633 cases (valid student questionnaires) and 72 characteristics or measures (answers given to each of the questions or variables analyzed).

The dataset was analyzed by means of Principal Components Analysis (PCA), which is a statistical method based on redimensioning the data under analysis (reducing the number of variables), for the analysis of the results from the questionnaire. In other words, having a set of data with multiple variables, the end purpose is to reduce the number of variables in an effort to minimize information loss, in so far as possible, for the new data. 
The new factors of principal components obtained through the redimensioning process are the result of a linear combination of the original variables and will, in turn, be independent from each other.

This technique was initially developed by Pearson [73] at the start of the 20th century, then studied and developed by Hotelling [74] and, more recently, has been applied in many studies on entrepreneurial intention in students $[10,29,30,46,68,69]$. The technique has two functions; on the one hand, it permits the optimal projection of the observations of a general N-dimensional space onto a space of reduced dimensionality (the principal components are the first step in identifying the possible latent or non-observed variables that generate the data), and on the other hand, it permits the transformation of the original variables, which are generally correlated, into new uncorrelated variables, facilitating the interpretation of the data. If we start with a set of multivariable data, the endpurpose is to redimension this data set so that it has a smaller number of variables in decreasing order of importance and with the minimum loss of information so that the resulting variables are a linear combination of the original variables and are independent of each other.

The orthogonal base that maximizes the variance of the data must be found in order to project data onto a space of reduced dimensionality. To do so, the projection has to be established with the maximum variance, which will correspond to the first vector of the base (the first principal component). Subsequently, the projection that contains the highest remaining variance will have to be determined, which will correspond to the second vector of the base (the second principal component) and so on successively. When the data are projected onto the first principal components, these will reduce the dimensionality accompanied by as much variance in the data as possible.

According to Bishop [75], PCA may be described as a map of vectors, $\mathrm{Xd}$, projected onto an $\mathrm{N}$ dimensional space on vectors, $\mathrm{Yd}$, in an $\mathrm{M}$-dimensional space, where $\mathrm{M}<=\mathrm{N}$, while $\mathrm{X}$ may be represented as a linear combination of a set of $\mathrm{N}$ orthonormal vectors $\mathrm{Wi}$ :

$x=\sum_{i=1}^{N} y_{i} W_{i}$

The vectors Wi satisfy the following relation of orthonormality:

$$
W_{i}^{t} W_{j}=\delta_{i j}
$$

where $\delta$ ij is the delta of Kronecker.

\section{Results}

Following the analysis of the variables based on the data obtained with the questionnaire, the PCA projection of the dataset is shown in Figure 3, where each point is the representation of each one of the 1,633 valid cases (student questionnaires) with its 72 selected characteristics (answers given to each of the questions or variables). In the analysis of the projection, we identify four groups in which the cases are distributed according to proximity and neighborhood. Clusters 1.1 and 1.2 correspond to the cases furthest from the part with the highest density and groups 3.1 and 3.2 correspond to the densest clusters (see Figure 3). 
PCA

Componentes 1-2

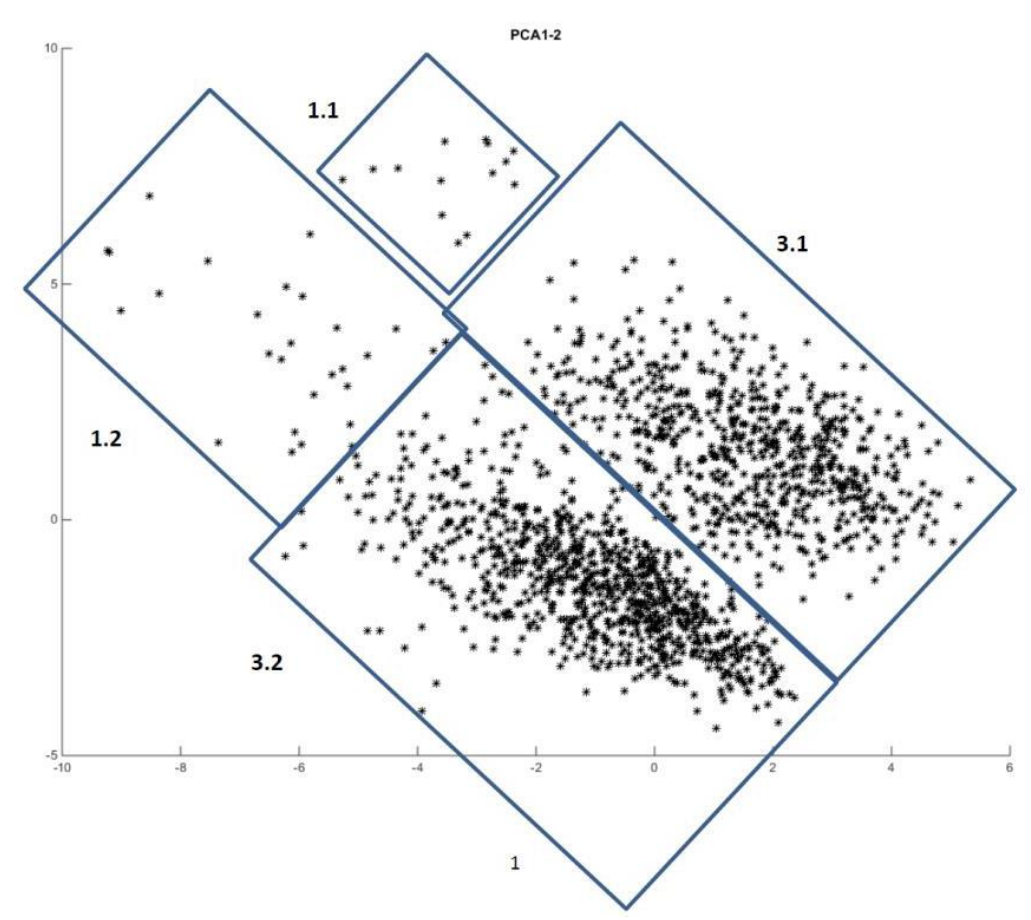

Figure 3. Results of the principal components analysis (PCA) analysis of the available data

Based on the proposed work objectives, we analyzed the average scores of youth entrepreneurial interest (EI), the family's interest for the young becoming entrepreneurial (EIC) and family support (FS), for each of the clusters resulting from applying the PCA technique (see Table 2):

Table 2. This is a table. Average scores of entrepreneurial interest (EI) and family's interest for the young becoming entrepreneurial (EIC) and number of subjects per group

\begin{tabular}{ccccc}
\hline Group & EI & EIC & Family support & Number of subjects \\
\hline 1.1 & 1 & 3.6 & 3.1 & 14 \\
1.2 & 1.75 & 1.4 & 1.25 & 28 \\
3.1 & 3 & 3.5 & 3.8 & 690 \\
3.2 & 2.9 & 1 & 1 & 901 \\
Null cases & & & & 131 \\
\hline
\end{tabular}

We established a Cartesian axis as a function of the results in which the projections yielded by the PCA are found (Figure 4). We then considered the number of subjects present in each of the established groupings and the average scores of the variables in use, the family interest in their child becoming entrepreneurial and the family support that would be given if the young person decided to become an entrepreneur, discriminating and dividing the group into a larger number of individuals. We therefore found that Group 3.1 obtained high results for both EI, EIC and FS; 3.2 obtained high results for EI and low results for EIC and FS, and Group 1.2 had low results for both EI, EIC and FS. 


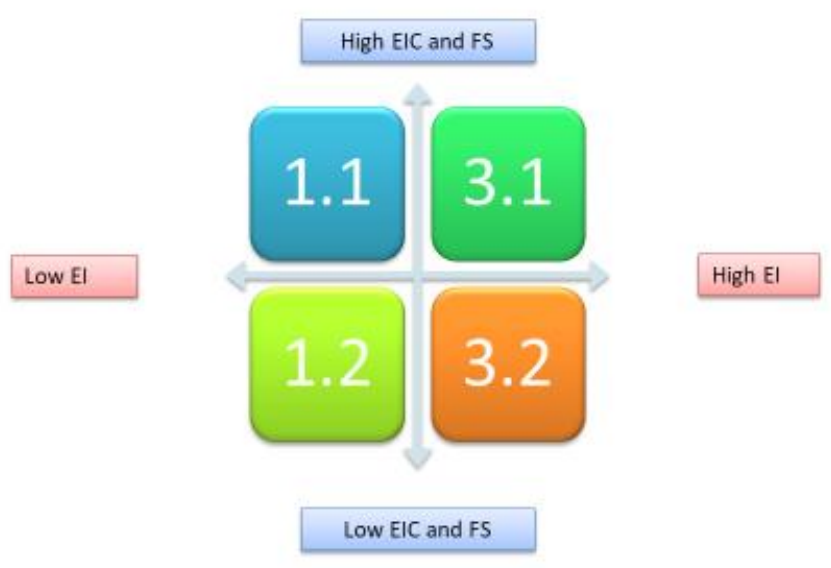

Figure 4. Representation of the average scores in EI, EIC and family support (FS) in accordance with the groupings of the PCA projection.

Having arranged the groups as functions of the PCA projections and the scores attained for the variables EI, EIC and FS, we completed the characterization of each group in accordance with the responses obtained to the questions that form the unit of analysis (Table 3). We collected the following results, shown in Table 2, from the first section of questions referring to the survey data on the student profile.

Based on the groupings obtained by the application of the PCA technique, we show the results obtained for each category analyzed both from the questionnaire of the young person and from the questionnaire of the families (Table 3).

Table 3. Percentages of the responses to the section on student data in the Student Questionnaire and in the Family Questionnaire.

\begin{tabular}{|c|c|c|c|c|c|c|}
\hline \multirow{3}{*}{$\begin{array}{c}\text { Type of } \\
\text { Questionnaire } \\
\text { Student } \\
\text { Questionnaire }\end{array}$} & \multirow{4}{*}{$\begin{array}{c}\begin{array}{c}\text { Question } \\
\text { number }\end{array} \\
\begin{array}{c}\text { Q. 1 Sex } \\
\text { students by } \\
\text { group }\end{array}\end{array}$} & \multirow[t]{2}{*}{ Categories } & \multicolumn{4}{|c|}{ Groups } \\
\hline & & & 1.1 & 1.2 & 3.1 & 3.2 \\
\hline & & Woman & $36 \%$ & $18 \%$ & $57 \%$ & $48 \%$ \\
\hline & & Man & $64 \%$ & $82 \%$ & $43 \%$ & $52 \%$ \\
\hline & \multirow[t]{4}{*}{$\begin{array}{l}\text { Q.10.1 Parental } \\
\text { education }\end{array}$} & $\begin{array}{l}\text { Only father with } \\
\text { higher education }\end{array}$ & $14 \%$ & $11 \%$ & $10 \%$ & $10 \%$ \\
\hline & & $\begin{array}{l}\text { Both with higher } \\
\text { education }\end{array}$ & $57 \%$ & $64 \%$ & $54 \%$ & $51 \%$ \\
\hline & & $\begin{array}{l}\text { Only mother with } \\
\text { higher education }\end{array}$ & $0 \%$ & $4 \%$ & $15 \%$ & $9 \%$ \\
\hline & & $\begin{array}{c}\text { None with higher } \\
\text { education }\end{array}$ & $29 \%$ & $21 \%$ & $21 \%$ & $30 \%$ \\
\hline
\end{tabular}




\begin{tabular}{|c|c|c|c|c|c|}
\hline \multirow[t]{4}{*}{$\begin{array}{c}\text { Q.10.2 } \\
\text { Entrepreneur } \\
\text { families }\end{array}$} & $\begin{array}{c}\text { Only } \\
\text { entrepreneurial } \\
\text { father }\end{array}$ & $14 \%$ & $28 \%$ & $20 \%$ & $23 \%$ \\
\hline & $\begin{array}{c}\text { Only } \\
\text { entrepreneurial } \\
\text { mother }\end{array}$ & $28 \%$ & $18 \%$ & $25 \%$ & $18 \%$ \\
\hline & $\begin{array}{c}\text { Both } \\
\text { entreprenuers }\end{array}$ & $29 \%$ & $36 \%$ & $32 \%$ & $35 \%$ \\
\hline & $\begin{array}{l}\text { None } \\
\text { entrepreneur }\end{array}$ & $29 \%$ & $18 \%$ & $23 \%$ & $24 \%$ \\
\hline \multirow{6}{*}{$\begin{array}{c}\text { Q. } 20 \text { Family } \\
\text { life }\end{array}$} & Ideal FL & 3.7 & 2.2 & 3.7 & 3.5 \\
\hline & Excellent FL & 3.9 & 2.2 & 3.8 & 3.5 \\
\hline & $\begin{array}{c}\text { Satisfaction with } \\
\text { FL }\end{array}$ & 4.2 & 2.6 & 4.1 & 3.9 \\
\hline & Achieve FL & 3.5 & 2.1 & 3.7 & 3.5 \\
\hline & Change FL & 3.7 & 1.8 & 3.4 & 3.2 \\
\hline & Own FL & 4.6 & 3.5 & 4.4 & 4.3 \\
\hline \multirow{10}{*}{$\begin{array}{l}\text { Q.37 Studies } \\
\text { (S.) and Job (J.) } \\
\text { market }\end{array}$} & $\begin{array}{l}\text { S. help achieve } \\
\text { sucess }\end{array}$ & 1 & 1.6 & 4.2 & 4.1 \\
\hline & $\begin{array}{l}\text { S. help to find } \\
\text { work }\end{array}$ & 1 & 1.6 & 4.2 & 4.2 \\
\hline & $\begin{array}{c}\text { S. help with social } \\
\text { relations }\end{array}$ & 1 & 1.7 & 3.8 & 3.7 \\
\hline & $\begin{array}{l}\text { S. help to earn } \\
\text { money }\end{array}$ & 1 & 1.1 & 3.8 & 3.8 \\
\hline & $\begin{array}{l}\text { S. help though } \\
\text { prefer to work }\end{array}$ & 1 & 1.6 & 1.8 & 2.1 \\
\hline & $\begin{array}{l}\text { J. helps to become } \\
\text { independent }\end{array}$ & 1 & 2.2 & 4.1 & 4.1 \\
\hline & $\begin{array}{c}\text { J. helps family } \\
\text { conviviality }\end{array}$ & 1 & 1.5 & 3.8 & 3.9 \\
\hline & $\begin{array}{c}\text { J. helps me to feel } \\
\text { useful }\end{array}$ & 1 & 1.7 & 4.1 & 4.1 \\
\hline & $\begin{array}{l}\text { J. helps to eam } \\
\text { money }\end{array}$ & 1 & 2 & 4.4 & 4.4 \\
\hline & $\begin{array}{c}\text { J. helps and is } \\
\text { worth searching } \\
\text { for }\end{array}$ & 1 & 1.8 & 3.9 & 4 \\
\hline \multirow{8}{*}{$\begin{array}{l}\text { Q.42 Motives } \\
\text { form creating } \\
\text { business }\end{array}$} & Family tradition & $0 \%$ & $0 \%$ & $8 \%$ & $9 \%$ \\
\hline & $\begin{array}{c}\text { Economic } \\
\text { independence }\end{array}$ & $0 \%$ & $43 \%$ & $56 \%$ & $53 \%$ \\
\hline & $\begin{array}{c}\text { Social } \\
\text { reconogtion }\end{array}$ & $0 \%$ & $7 \%$ & $41 \%$ & $36 \%$ \\
\hline & $\begin{array}{c}\text { Create } \\
\text { employment }\end{array}$ & $0 \%$ & $7 \%$ & $41 \%$ & $36 \%$ \\
\hline & Find work & $0 \%$ & $18 \%$ & $32 \%$ & $36 \%$ \\
\hline & Direct & $0 \%$ & $7 \%$ & $14 \%$ & $13 \%$ \\
\hline & Earn money & $0 \%$ & $43 \%$ & $57 \%$ & $62 \%$ \\
\hline & $\begin{array}{c}\text { Put ideas into } \\
\text { practice }\end{array}$ & $0 \%$ & $18 \%$ & $61 \%$ & $57 \%$ \\
\hline
\end{tabular}




\begin{tabular}{|c|c|c|c|c|c|c|}
\hline & & $\begin{array}{l}\text { Contribute to } \\
\text { development }\end{array}$ & $0 \%$ & $14 \%$ & $34 \%$ & $32 \%$ \\
\hline & \multirow{10}{*}{$\begin{array}{c}\text { Q.43 } \\
\text { Difficulties of } \\
\text { entrepreneurs } \\
\text { hip }\end{array}$} & Risk & $0 \%$ & $21 \%$ & $45 \%$ & $51 \%$ \\
\hline & & Institut support & $0 \%$ & $14 \%$ & $41 \%$ & $32 \%$ \\
\hline & & Negative image & $0 \%$ & $4 \%$ & $7 \%$ & $8 \%$ \\
\hline & & Family support & $0 \%$ & $14 \%$ & $4 \%$ & $9 \%$ \\
\hline & & A lot of work & $0 \%$ & $4 \%$ & $18 \%$ & $20 \%$ \\
\hline & & Failure & $0 \%$ & $25 \%$ & $63 \%$ & $62 \%$ \\
\hline & & Bureacracy & $0 \%$ & $14 \%$ & $19 \%$ & $19 \%$ \\
\hline & & Lack of money & $0 \%$ & $25 \%$ & $76 \%$ & $74 \%$ \\
\hline & & Training & $0 \%$ & $4 \%$ & $17 \%$ & $15 \%$ \\
\hline & & No ideas & $0 \%$ & $11 \%$ & $21 \%$ & $22 \%$ \\
\hline \multirow[t]{3}{*}{$\begin{array}{c}\text { Family } \\
\text { Questionnaire }\end{array}$} & \multirow{3}{*}{$\begin{array}{l}\text { Q. 18.2 Type of } \\
\text { support for } \\
\text { entrepreneurs } \\
\text { hip }\end{array}$} & $\begin{array}{l}\text { Economic } \\
\text { Support }\end{array}$ & 3.4 & 1.3 & 3.6 & 1 \\
\hline & & Moral Support & 4.9 & 1.6 & 4.7 & 1.1 \\
\hline & & Ideas & 4.3 & 1.5 & 4.3 & 1.1 \\
\hline
\end{tabular}

Continuing with the groupings resulting from the application of the PCA technique, we described the characteristics of each of them based on the aspects analyzed:

Group 1.1: Low entrepreneurial interest (EI); high family interest for the young entrepreneur (EIC) and high family support (FS).

From the student questionnaire, we see that this group includes mainly men (64\%) (Q.1), with both parents have a higher level of education (57\%) (Q.10.1) and the percentage of families where the mother is the entrepreneur is of $28 \%, 14$ points higher than families where only the entrepreneur is the father (Q.10.2). Members of this group feel highly satisfied with their family life (Q. 20). They do not perceive that studies or work will help them to improve their lives (Q. 37). They do not show answers as regards the motivations (Q. 42) to create a company or difficulties (Q. 43).

From the questionnaire applied to families, the most prevalent type of support from the families is moral support, with a score of 4.9 out of 5 (Q. 18.2).

Group 1.2: Low entrepreneurial interest (EL); low family interest for the young entrepreneur (EIC) and low family support (FS).

From the student questionnaire we see that this group includes mainly men $(82 \%)(\mathrm{Q} .1)$, with both parents having a higher level of education $(64 \%)(Q .10 .1)$ and the percentage of families where the father is the entrepreneur is $28 \%, 10$ points higher than families where the only entrepreneur is the mother (Q.10.2). Members of this group are not very satisfied with their family life (Q. 20), with the feature with the highest score being the one that refers to the creation of their own family, with an average score of 3.5 out of 5 . The perception of how studies and work help in their life (Q.37) displays scores below 2.5 out of 5. The motivations (Q. 42) to create a company that the respondents have selected to a greater extent are economic independence (43\%) and to earn money (43\%). The difficulties that are perceived in creating a company (Q. 43) are fear of failure (25\%), lack of money to start (25\%) and risk (21\%).

From the questionnaire applied to families, none of the categories related to the family support exceeds the score of 2.5 out of 5 , the highest one being moral support with 1.6 (Q. 18.2).

Regarding these groups 1.1 and 1.2, although the sample sizes were 14 and 28, respectively, they do provide useful information. Specifically, these groups point to the need to consider family interest as a key aspect in shaping the entrepreneurial system of young people.

Group 3.1: High entrepreneurial interest (EI); high family interest for the young entrepreneur (EIC) and high family support (FS).

From the student questionnaire, we see that this group includes mainly women (57\%) (Q.1), with both parents having a higher level of education (54\%) (Q.10.1). It should also be noted that the 
percentage in which the only has the mother has higher education (15\%), is the largest of all groupings. In this grouping, the percentage of families where the mother is the entrepreneur is $25 \%$, five percentage points higher than families where only the father is the entrepreneur (Q.10.2). Members of this group are highly satisfied with their family life (Q.20) in all aspects analyzed, ranking higher than 3.4 out of 5 . In the perception of how studies help them (Q.42), the aspects related to being successful in life and finding a job obtain scores above 4 out of 5 . Referring to how work helps, the aspects related to having money, feeling useful and becoming independent give scores of above 4 out of 5 . The motivations (Q.42) to create companies that were pointed out more often by the young people surveyed are: putting my ideas into practice $(61 \%)$; earning money $(57 \%)$ and having economic independence $(56 \%)$. The difficulties that precede creating a company (Q.43) include a lack of money $(76 \%)$ and a fear of failure $(63 \%)$.

In the questionnaire applied to families, the most prevalent type of support from the families is the moral support, with a score of 4.7 out of 5 (Q. 18.2).

Group 3.2: High entrepreneurial interest (EI); low family interest for the young entrepreneur (EIC) and low family support (FS).

From the student questionnaire, we see that this group is relatively evenly split between men and women (52\% men) (Q.1), with both parents with higher education (51\%) (Q.10.1), where the families in which the entrepreneur is the father are $23 \%$, five points higher than the families in which the only entrepreneur is the mother (Q.10.2). Members of this group are highly satisfied with their family life (Q.20) in all the aspects analyzed, ranking higher than 3 out of 5 . In the perception of how studies and work help them (Q.42), students obtain scores above 4 out of 5 in all aspects analyzed. The motivations (Q.42) to create companies more often indicated by the young people surveyed are: putting my ideas into practice (57\%); earning money $(62 \%)$ and having economic independence $(53 \%)$. The difficulties that arise when creating a company (Q.43) are a lack of money (74\%), fear of failure $(62 \%)$ and risk (51\%).

From the questionnaire applied to families, none of the categories related to the family support exceeds the score of 2.5 out of 5 , the highest ones being moral support and ideas with 1.1 (Q. 18.2).

\section{Discussion}

The resulting PCA projections provide us with a distribution among the groups, where the determination of the groups' characteristics is useful for decision making in the fields of economic, educational, and curricular policy. Decisions oriented towards increasing entrepreneurial intention and its transformation into entrepreneurial action necessarily have to consider the characteristics of the group in line with the suggestions of previous studies [4,26-28,31]. In earlier works, the usefulness of PCA has been shown in multiple fields, ranging from the economic analysis of political risk [76] and in the area of computing [77] to the psychological aspects of entrepreneurship [36]. We contribute by applying this technique to the socio-educational analysis of entrepreneurship. PCA provides a visualization of sample distribution patterns in accordance with the variables, which is a fundamental reference for subsequent decision-making in aspects as crucial as the social and the educational influence of the family.

In relation to the first objective (to describe the association between interest in entrepreneurship among Spanish youths and the family's interest in their child becoming entrepreneurial), the data showed that the young population has a medium interest in entrepreneurship. The results from the PCA demonstrate that the family interest influences the distribution of the cases, which allows us to identify and describe the characteristics of distinct groups in order to facilitate decision making. In general, these results corroborate the literature, which has established the influence of the family as a network of local entrepreneurship [40,61,63,65-67,70-72].

On the second objective regarding the relationship between the entrepreneurial interest of young people and family support that the young person would receive if he decided to become an entrepreneur, the results show that family support influences the distribution of the projections of the 
cases studied, as is the case with the family interest for the child becoming entrepreneurial. Both scores (interest and family support) are similar in the groupings made. These results respond to questions that authors as Heck and Rogoff [67], Aldridh and Cliff [16], and Gibb Dyer [15] posed, pointing to a clear influence of the family on the entrepreneurial interest of young people

Regarding the third objective (to analyze what kind of family support is more prevalent among Spanish youths with high entrepreneurial interest and with families with a high interest in their children being entrepreneurs), the grouped projections in which there is a high entrepreneurial interest of young people, together with a high interest and family support, showed that the kind of support they would receive to a greater extent is of the moral kind, rather than in economic means or ideas.

Another interesting aspect to consider is the results obtained between parental education level and entrepreneur families, where it is observed that the percentages that fluctuate most in the groupings with high family interest and high entrepreneurial interest are those related to the level of studies of the mother and the fact that the mother is the entrepreneur of the family. That is, families in which the mothers are entrepreneurs and have a higher level of education show higher levels of interest and family support for their child to become an entrepreneur.

\section{Conclusions}

In this study, we focus on the role of the family as a factor influencing entrepreneurial interest among Spanish youths. The evaluation of family interest had been given scant attention in the study of entrepreneurship until only a few years ago. The under-estimation of family interest combined with psychological and socio-educational variables suggests the advisability, in terms of practical applications, of lending greater attention to the early detection of incipient entrepreneurial interest among young people and to attributing due importance to the interest of the family in the design of actions to stimulate entrepreneurial culture.

One of the limitations of this work is related to the cross-sectional nature of the study, since the causal relation between the variables under study and entrepreneurial interest cannot be detected. Therefore, in a future investigation, longitudinal designs are proposed in which evidence might be unearthed regarding the relations between the variables in the context of the effects that are identified. Another limitation is related to the single-item nature of the questionnaire. Despite the fact that the validity and reliability of the questionnaire was confirmed through a pilot test conducted in eight autonomous communities in Spain, and was evaluated by 14 experts belonging to seven Spanish universities and its reliability was contrasted with previous studies using this same questionnaire, it would be advisable to corroborate the results employing other alternative measures. Likewise, another limitation of this study is related to the generalization of the results, given the small samples in groups 1.1 and 1.2. Yet, it is also important to note that the fact that certain groups of data in PCA visualizations contain a small amount of data does not mean that they are useless. Actually, PCA and other EPP techiques are frequently applied to identify outliers (including cases of one single datum isolated from the other data groups).

Finally, future studies could also employ additional techniques such as cluster analysis, linear regression or latent class/profile analysis to enlarge the findings and address additional research questions.

Despite the aforementioned limitations, overall, this study contributes to the growing trend in the literature studying not only the economic, but also the socio-educational aspects related to entrepreneurship, highlighting the role of the family as factor with a significant influence on entrepreneurial interest among the Spanish youth.

Author Contributions: conceptualization, M.C.E.LL. and M.I.L.R.; methodology, M.C.E.LL. and M.I.L.R software, A.H.C.; validation, C.P.C., A.J.E. and T.D.L.T.C.; formal analysis, A.H.C.; investigation, M.C.E.LL., T.D.L.T.C. and M.I.L.R.; resources, A.J.E. and C.P.C.; data curation, M.I.L.R.; writing-original draft preparation, M.C.E.LL.; writing-review and editing, A.J., T.D.L.T.C.; 
visualization, M.C.E.LL., M.I.L.R, A.H.C. and A.J.; supervision, A.J., T.D.L.T.C.; project administration, A.J.E.; funding acquisition, C.P.C.

Funding: This research was funded by Ministry of Economy and Competitiveness. Government of Spain. Grant Number: EDU 2012-39080-C07-00 a 07.

Conflicts of Interest: The authors declare no conflict of interest. The funders had no role in the design of the study; in the collection, analyses, or interpretation of data; in the writing of the manuscript, or in the decision to publish the results

\section{References}

1. Brás, G.R.; Soukiazis E. The determining factors of entrepreneurship in Portugal. Rev Port e Bras Gestão 2015,14(3),13-25.

2. Serrano-Bedia, A.M; Pérez-Pérez, M.; Palma-Rui, M.; López-Fernández, MC. Emprendimiento: visión actual como disciplina de investigación. Un análisis de los números especiales publicados durante 20112013. Estud Gerenciales 2016,32(138),82-95.

3. Betancor, M.V. Empoderamiento: $¿$ una alternativa emancipatoria?: reflexiones para una aproximación crítica a la noción de empoderamiento. Margen Rev Trab Soc y ciencias Soc 2011,61,1-14.

4. Sánchez, J.C. Entrepreneurship: introduction. Psicothema 2011,23(3),424-426.

5. Torres-Granadillo, F.; Artigas, W. Emprendimiento económico: Elementos teóricos desde las perspectivas de sistemas y redes. Rev Ciencias Soc 2015,21(3),429-41.

6. Moya, M. Worldwide business startups [Internet]. 2008 [cited 2017 Jan 18]. Available from: www.moyak.com/researcher/resume/papers/business_startups.html

7. Agarwal, R.; Audretsch, D.; Sarkar, M. The process of creative construction: knowledge spillovers, entrepreneurship, and economic growth. Strateg Entrep J 2007,1(3-4),263-286.

8. Baumol, W.J. The Free-Market Innovation Machine: Analyzing the Growth Miracle of Capitalism. Princeton University Press, Princeton, NJ, 2004.

9. Baumol, W.J.; Strom, R.J. Entrepreneurship and economic growth. Strateg Entrep J 2007,1(3-4),233-237.

10. Voda, A.I.; Covatariu, D.; Ghiuta, O-A. Student's entrepreneurial intentions: role of entrepreneurial education and risk taken ability. Environ Eng Manag J [Internet] 2019, 18(7), 1527-34. Available from: http://www.eemj.eu/index.php/EEMJ/article/view/3909

11. Grilo, I.; Thurik, R. Entrepreneurial engagement levels in the European Union. Int J Entrep Educ 2005, 3(2),143-168.

12. Dau, L.A.; Cuervo-Cazurra, A. To formalize or not to formalize: entrepreneurship and pro-market institutions. J Bus Ventur 2014, 29(5), 668-686.

13. Freytag, A. Thurik R. Entrepreneurship and its determinants in a cross-country setting. J Evol Econ 2007, $17(2), 117-131$.

14. Uhlaner, L.; Thurik, R.; Freytag, A.; Thurik, R.; Dau, L.A.; Cuervo-Cazurra, A. To formalize or not to formalize: entrepreneurship and pro-market institutions. J Evol Econ 2007, 17(2), 117-131.

15. Gibb Dyer, W. Examining the "Family Effect" on Firm Performance. Fam Bus Rev. 2006, 19(4), 253-73.

16. Aldrich, H.E.; Cliff, J.E. The pervasive effects of family on entrepreneurship: Toward a family embeddedness perspective. J Bus Ventur 2003, 18(5), 573-96.

17. European Commission. Commission Green Paper on Entrepreneurship in Europe. COM (2003). [Internet]. 2003 [cited 2017 Jan 18]. Available from: http://ec.europa.eu/invest-inresearch/pdf/download_en/entrepreneurship_europe.pdf

18. European Commission. Entrepreneurship. Flash Eurobarometer 134. Directorate General Enterprises: Bruselas, 2002. 
19. European Commission. Best procedure" project on education and training in entrepreneurship. Report of the Expert Group. D.G. Empresa: Belgium, 2002.

20. Communication from the Commission 2020. A strategy for smart, sustainable and inclusive growth [Internet]. 2010 [cited 2016 Apr 22]. Available from: http://eurlex.europa.eu/LexUriServ/LexUriServ.do?uri=COM:2010:2020:FIN:EN:PDF

21. Council D 2014/59/EU of the EP and of the. Establishing a framework for the recovery and resolution of credit institutions and investment firms and amending Council Directive 82/891/EEC, and Directives 2001/24/EC, 2002/47/EC, 2004/25/EC, 2005/56/EC, 2007/36/EC, 2011/35/EU, 2012/30/EU and 2013/36/E [Internet]. 2014 [cited 2016 May 15]. Available from: http://eurlex.europa.eu/legalcontent/EN/TXT/PDF/?uri=CELEX:32014L0059\&rid=2

22. Dutta, N.; Sobel, R.S.; Roy, S. Entrepreneurship and political risk. J Entrep Public Policy 2013, 2(2), 130143.

23. Jiménez Palmero, A.; Palmero Cámara, C.; Jiménez Eguizábal, A. El impacto de la educación secundaria y superior en la creación de empresas en la Unión Europea. Rev Esp Pedagog 2012, 70(252), 201-19.

24. Welsh, D.H.B.; Tullar, W.L.; Nemati, H. Entrepreneurship education: Process, method, or both? J Innov Knowl [Internet]. 2016, 1(3), 125-32. Available from: http://dx.doi.org/10.1016/j.jik.2016.01.005

25. Mason, C.; Brown R. Entrepreneurial Ecosystems and Growth Oriented Entrepreneurship. In: Background paper prepared for the workshop organised by the OECD LEED programme and the Dutch ministry of economic affairs The Hague, Netherlands , 7 November 2013 [Internet]. The Hague: Programme and the Dutch Ministry of Economic Affairs: Dutch, 2014. p. 1-38. Available from: https://www.oecd.org/cfe/leed/Entrepreneurial-ecosystems.pdf

26. Schøtt, T.; Wickstrøm Jensen, K. La conexión entre el emprendimiento y la política pública: Bien ajustada en los países desarrollados, pero suelta en los países en desarrollo. Estud Econ 2008,35(2), 195-214.

27. Simón, J.D. Systematizing experiences in entrepreneurship education in elementary schools. Rev Mex Investig Edu 2013, 18(56), 159-90.

28. UNESCO. Proyecto de estrategia para la enseñanza y formación técnica y profesional (EFTP) (20162021). [Internet]. 2016 [cited 2016 Nov 27]. Available from: http://unesdoc.unesco.org/images/0024/002438/243804s.pdf

29. Ayuni, N.W.D.; Sari, IGAMKK. Analysis of factors that influencing the interest of Bali State Polytechnic's students in entrepreneurship. J Phys Conf Ser [Internet] 2018, 953(1). Available from: https://iopscience.iop.org/article/10.1088/1742-6596/953/1/012071/pdf

30. Popescu, C.C.; Bostan, I.; Robu, I.B.; Maxim, A.; Diaconu, L. An Analysis of the Determinants of Entrepreneurial Intentions among Students: A Romanian Case Study. Sustainability 2016, 8(8), 771.

31. Shane, S.; Venkataraman, S. The promise of entrepreneurship as a field of research. Acad Manag Rev 2000, 25(1), 217-226.

32. Tarapuez, E.; García, M.D.; Castellano, N. Aspectos socioeconómicos e intención emprendedora en estudiantes universitarios del Quindío (Colombia). Innovar 2016, 28(37), 123-135.

33. Fayolle, A.; Gailly, B. The impact of entrepreneurship education on entrepreneurial attitudes and intention: Hysteresis and persistence. J Small Bus Manag 2015, 53(1), 75-93.

34. Nabi, G.; Walmsley, A.; Liñán, F.; Akhtar, I.; Neame, C. Does entrepreneurship education in the first year of higher education develop entrepreneurial intentions? The role of learning and inspiration. Stud High Educ 2018, 43(3), 452-67.

35. Fayolle, A.; Liñán, F. The future of research on entrepreneurial intentions. J Bus Res [Internet] 2014, $67(5), 663-6$. 
36. Escolar-Llamazares, M.C.; Luis-Rico, I.; de la Torre-Cruz, T.; Herrero, Á.; Jiménez, A.; Palmero-Cámara, C.; et al. The socio-educational, psychological and family-related antecedents of entrepreneurial intentions among Spanish Youth. Sustain 2019, 11(5), 1-21.

37. Lent, R.W.; Brown, S.D.; Hackett, G. Contextual supports and barriers to career choice: A social cognitive analysis. J Couns Psych 1994, 47, 36-49.

38. Lee, S.; Lim, S.; Pathank, R. Influences on students' attitudes toward entrepreneurship: a multi-country study. Int Entrep Manag J 2006, 2, 351-366.

39. Lanero, A.; Vázquez, J.L.; Muñoz-Adánez, A. A social cognitive model of entrepreneurial intentions in university students. An Psicol 2015, 31(1), 243-259.

40. Lent, R.W.; Brown, S.D.; Hackett, G. Toward a unifying social cognitive theory of career and academic interest, choice, and performance. J Voc Behav 1994, 45, 79-122.

41. Schröder, E.; Schmitt-Rodermund, E. Crystallizing enterprising interests among adolescents through a career development program: The role of personality and family background. J Voc Behav 2006, 69, 494509.

42. Schmitt-Rodermund, E.; Vondracek, F.W. Occupational dreams, choices and aspirations: Adolescents' entrepreneurial prospects and orientations. J Adol 2002, 25, 65-78.

43. Durán-Aponte, E.; Arias-Gómez, D. Intención Emprendedora En Estudiantes Entrepreneurial Intention in Undergraduate Students: Integration of Cognitive and Socio-Personal Factors. Rev Colomb Ciencias Soc [Internet] 2015, 6(2), 320-40. Available from: https://www.redalyc.org/pdf/4978/497856275007.pdf

44. Baron, R,A. OB and entrepreneurship: the reciprocal benefits of closer conceptual links. In Research in Organizational Behavior: An Annual Series of Analytical Essays and Critical Reviews.; Staw, B.M., Kramer, R.M., Eds.; Elsevier Science Publishing: Oxford, UK, 2002; pp. 225-269.

45. Montoya, I.; Valencia, A.; Montoya, A. Mapeo del campo de conocimiento en intenciones emprendedoras mediante el análisis de redes sociales de conocimiento. Ingeniare, Rev Chil Ing 2016, 24(2), 337-50.

46. Barton, M.; Schaefer, R.; Canavati, S. To Be or Not to Be a Social Entrepreneur: Motivational Drivers amongst American Business Students. Entrep Bus Econ Rev [Internet] 2018, 6(1), 9-35. Available from: https://eber.uek.krakow.pl/index.php/eber/article/view/329

47. Sonnenfelt, J.; Kotter, J.P. The maturation of career theory. Hum Relación 1982, 35, 19-46.

48. León, J.A.; Descals, F.J.; Domínguez, J.F. El perfil psicosocial del emprendedor universitario. Univ Rev Psicol del Trab y las Organ 2006, 22(1), 75-99.

49. Mortan, R.A.; Ripoll, P.; Carvalho, C.; Bernal, M.C. Journal of Work and Organizational Psychology. J Work Organ Psychol [Internet] 2014, 30(3), 97-104. Available from: http://jwop.elsevier.es/

50. Salazar-Carvajal, P.F.; Herrera-Sánchez, I.M.; Rueda-Méndez, S.; León-Rubio, J.M. The effect of conservation of resources on the entrepreneurial intention in the context of economic crisis: the moderating role of the self-efficacy and creativity. An Psicol 2014, 30(2), 549-59.

51. Torres, J.L.; Watson, W. An examination of the relationship between manager self-efficacy and entrepreneurial intentions and performance in Mexican small businesses. Contaduría y Adm 2013, 58(3), 65-87.

52. Soria-Barreto, K.; Zuniga-Jara, S.; Ruiz-Campo, S. Educación e Intención Emprendedora en Estudiantes Universitarios : Un Caso de. Form Univ 2016, 9(1), 25-34.

53. Cisneros, M.E. Desempeño de nuevos negocios: perspectiva de género. Contaduría y Adm 2015, 60(2), 468-485.

54. Serrano-Bedia, A.M.; Pérez-Pérez, M.; Palma-Ruiz, J. M.; López-Fernández, M. C. Emprendimiento: 
visión actual como disciplina de investigación. Un análisis de los números especiales publicados durante 2011-2013. Estud Gerenciales 2016, 32(138), 82-95.

55. Mason, C.M. Public policy support for the informal venture capital market in Europe: a critical review. Int Small Bus J 2009, 27(5), 536-556.

56. Premaratne, S.P. Networks, resources, and small business growth: the experience in Sri Lanka. J Small Bus Manag 2001, 39(4), 363-371.

57. Katz, J. A psychological cognitive model of employment status choice. Entrep Theory Pr 1992, 17(1), 2937.

58. Shapero, A.; Sokol, L. The social dimensions of enterpreneurship. In Encyclopedia of Entreprenurial Mind, Kent, C., Sexton, D., Vesper, K.H, Eds.; Springer: New York, USA, 1982; pp. 51-72.

59. Phelan, S.; Dalgic, T.; Li, D.; Sethi D. The development of entrepreneurial networks: a necessary condition for international new ventures? Steven E. Phelan University of Nevada Las Vegas University of Texas at Dallas Dan Li Texas A \& M University Deepak Sethi Oakland University School of Man. Strateg Manag Rev [Internet] 2006, 1(1), 1-21. Available from: http://faculty.unlv.edu/phelan/Research/INV2.pdf

60. Bolaños, R. Impacto del modelo a imitar en la intención de crear una empresa. Estud Econ Apl 2006, 24(2), 491-508.

61. Casson, M.; Giusta, M.D. Entrepreneurship and social capital: analysing the impact of social networks on entrepreneurial activity from a rational action perspective. Int Small Bus J 2007, 25(3), 220-244.

62. Herrera, H. Research into social and entrepreneurship networks: a literature review and future agenda. Innovar Rev Ciencias Adm y Soc 2009, 19(33), 19-33.

63. Pinho, J.C.; de Sá, E.S. Entrepreneurial performance and stakeholders' relationships: a social network analysis perspective. Int J Entrep 2013, 17(1), 1-20.

64. Feijó Cuenca, P.; Feijó Cuenca, T.; Bravo Giler, A. Analysis of factors that contribute in the entrepreneurial activity of young people. ECA Sinerg 2019, 10(2), 59-68.

65. Moriano, J.A.; Palací, F.J.; Morales, J.F. El perfil psicosocial del emprendedor universitario. Rev Psicol del Trab y las Organ 2006, 22(1), 75-99.

66. Morant Martínez, O.; Santandreu-Mascarell, C.; Canós Darós, L.; Millet Roig, J. Valencia startup Ecosystem: una aproximación al ecosistema emprendedor de Valencia y sus características frente a los rankings internacionales. Econ Ind, 2017, 404, 63-70.

67. Rogoff, E.G.; Zachary Heck, R.K. Evolving research in entrepreneurship and family business: Recognizing family as the oxygen that feeds the fire of entrepreneurship. J Bus Ventur 2003, 18(5), 55966.

68. Canever, M.; Barral, M.; Ribeiro, F. How does the public and private university environment affect students' entrepreneurial intention? Educ + Train, 2017, 59(6), 550-64.

69. Yao, X.; Wu, X.; Long, D. University students' entrepreneurial tendency in China: Effect of students' perceived entrepreneurial environment. J Entrep Emerg Econ, 2016, 8(1), 60-81.

70. Rueda Sanpredro, I.; Fernández-laviada, A.; Herrero Crespo, A. Estudiantes universitarios y emprendimiento: determinantes psicológicos de la intención de creación de un negocio propio. Entrep Coll Students Psychol Determ own Bus Creat 2012, 1(2), 9-15.

71. Valdemoros-San-Emeterio, M.Á.; Ponce de León, A. Gradaille R. Actividad Física de Ocio Juvenil y Desarrollo Humano. Rev Psicol del Deport, 2016, 25, 39-44.

72. Valdemoros-San-Emeterio, M.A.; Sanz-Arazuri, E.; Ponce-de-León-Elizondo, A. Digital Leisure and Perceived Family Functioning in Youth of Upper Secondary Education. Comunicar, 2017, 25(50), 99-107. 
73. Pearson, K. On lines and planes of closest fit to systems of points in space. Philos Mag, 1901, 2(11), 55972.

74. Hotelling, H. Analysis of a complex of statistical variables into principal components. J Educ Psychol 1993, 24(6), 417-441.

75. Bishop, C.M. Neural Networks for Pattern Recognition. Oxford University Press: New York, NY, 1995.

76. Herrero, Á.; Corchado, E.; Jiménez, A. Unsupervised neural models for country and political risk analysis. Expert Syst Appl 2011, 38(11), 13641-13661.

77. Herrero, Á.; Zurutuza, U.; Corchado, E. A neural-visualization IDS for honeynet data. Int J Neural Syst 2012, 22(2), 1-18. 